\title{
Anuran species in a remnant of the Atlantic rainforest in an urban area
}

\section{Marcio Marques Mageski ${ }^{1,3,4,6}$; Thiago Silva-Soares ${ }^{2}$; Charles Duca ${ }^{1,3,4,7}$; Débora Cristina Medeiros ${ }^{1,3,4,8}$; Paulo Roberto Jesus ${ }^{1,9}$; Larissa Corteletti da Costa ${ }^{1,3,10}$ \& Rute Beatriz Garcia Clemente-Carvalho ${ }^{5}$}

1 Universidade Vila Velha (UVV). Campus Boa Vista. Vila Velha, ES, Brasil.

2 Instituto Nacional da Mata Atlântica (INMA), Museu de Biologia Prof. Mello Leitão (MBML), Laboratório de Zoologia. Santa Teresa, ES, Brasil. E-mail:thiagosilvasoares@hotmail.com

3 Programa de Pós-Graduação em Ecologia de Ecossistemas (PPGEE).

${ }^{4}$ Laboratório de Ecologia de Populações e Conservação (LEPC).

${ }^{5}$ Queen's University, Department of Biology. Kingston, Ontario, Canada. E-mail: rute beatriz@hotmail.com

${ }^{6}$ ORCID: 0000-0001-7528-072X. E-mail: marcioherpetologia@gmail.com (corresponding author)

7 ORCID: 0000-0003-3903-8260. E-mail: cduca@uvv.br

${ }^{8}$ E-mail: deboracbio@gmail.com

${ }^{9}$ ORCID: 0000-0003-2666-8618. E-mail: filhopri@gmail.com

${ }^{10}$ ORCID:0000-0002-2821-2561. E-mail: larissacortelettibio@gmail.com

\begin{abstract}
Forest fragments in urban areas have many habitat resources that frogs use for refuge, reproduction and growth. Knowledge of an anuran assembly is the first step towards understanding the importance of these forest fragments in areas highly threatened by anthropogenic actions. We sampled anurans during the day and night from November 2012 to August 2013 through visual and acoustic surveys. We found 333 individuals belonging to 19 species. The highest richness and abundance were recorded in January whereas the lowest richness and abundance were recorded in June. Most species were found in open areas. Our results highlight the importance of well-studied urban fragments for the anuran community. The conservation of these habitats may ensure the viability of the ecological functions of this anuran community for the future.
\end{abstract}

Key-Words. Amphibian; Community; Habitat loss; Refuge; Conservation.

\section{INTRODUCTION}

The Atlantic Forest is under severe fragmentation and loss due to human colonization, which poses several threats to native biodiversity (Ribeiro et al., 2009; Tabarelli et al., 2010). Fragmentation and habitat loss change the forest structure and local climate, and as a consequence the temperature and humidity are also modified (Felix et al., 2004; Gandinetti \& Jacobi, 2005; Cushman, 2006). Nevertheless, some of the remaining fragments play an important role as refuge for many species in some regions of the Atlantic Forest domain (Rocha et al., 2004; Martins et al., 2014).

Urban forest fragments may provide survival conditions for several organisms including plants, invertebrates and vertebrates (Rodrigues et al., 1993; Miyashita et al., 1998; Azevedo et al., 2002; Brown \& Freitas, 2002; Estrada \& Coates-Estrada, 2002; Pontes \& Soares, 2005; Tsuji-Nishikido, 2011; Diamond \& Heinen, 2016). Anurans have specific requirements for habitat occupancy that are usually related to their reproductive mode (Duellman \& Trueb, 1994; Almeida-Gomes \& Rocha, 2015). Species are either specialists that require a spe- cific habitat for reproduction (e.g., bromeliads) or opportunistic that are able to reproduce in different types of habitats (e.g., ponds, streams and rivers) (Duellman \& Trueb, 1994; Haddad et al., 2013).

In this study, we assessed the composition, spatial distribution, and diversity of anuran community inhabitants in urban forest fragment in southeastern Brazil.

\section{MATERIAL AND METHODS}

We studied the amphibian community at Parque Estadual da Fonte Grande (hereafter PEFG), in the municipality of Vitória, in the state of Espírito Santo, southeastern Brazil $\left(20^{\circ} 18^{\prime} \mathrm{S}\right.$ and $40^{\circ} 20^{\prime} \mathrm{W}, 300 \mathrm{~m}$ asl., Fig. 1). PEFG comprises ca. 218 ha of Atlantic Forest, mostly of secondary vegetation (Griffo \& Silva, 2013). The climate is monsoon (Am) according to the revised KöppenGeiger's climate classification (Alvares et al., 2013).

Anurans were recorded monthly during the day (08:00-12:00 h) and night (18:00-23:00 h), from November 2012 to August 2013 through visual and acoustic surveys in permanent ponds, 
temporary and permanent streams, forest leaf-litter, and bromeliads, because these were the sites in PEFG in which anurans were most likely to be found. The individuals were hand captured and maintained in plastic bags for identification. Afterwards, all individuals were released in the same site where they were captured. Some specimens (ca. five individuals per species) were collected and euthanized with topical lidocaine (CEBEA, 2013), fixed in $10 \%$ formalin and preserved in $70 \%$ alcohol (Auricchio \& Salomão, 2002). Vouchers specimens were deposited in the Museu Nacional at Universidade Federal do Rio de Janeiro (MN/UFRJ) and Eugenio Izecksohn at Universidade Federal Rural do Rio de Janeiro (EI/UFRRJ). In order to evaluate sampling effectiveness, we ran a species rarefaction curve with 1,000 randomizations of the original dataset using Biodiversity $\mathrm{R}$ package (Kindt, 2016) in R 3.3.0 ( $\mathrm{R}$ Development Core Team, 2016). For each species, we obtained data of conservation status and population trends from the Red List of the International Union for Conservation of Nature (IUCN, 2017). We categorized the habitat requirements of the species: "forest dependent", "open landscapes" and "habitat generalist" (when they occupy both forest and open landscapes) (Teixeira et al., 2008; Haddad et al., 2013).

\section{RESULTS}

We recorded 333 individuals belonging to 19 species and seven families (Table 1). The species rarefaction curve stabilized in 20 species (Fig. 2), indicating that our sampling was sufficient to record all potential species in PEFG. All recorded species were classified as "Least Concern". Three species (15\%) have decreasing population trends (IUCN, 2017). The highest richness $(\mathrm{N}=9)$ and abundance $(\mathrm{N}=84)$ were recorded in January (rainy season) whereas the lowest richness $(\mathrm{N}=4)$ and abundance $(\mathrm{N}=9)$ were recorded in June (dry season).

\section{DISCUSSION}

The number of species recorded at PEFG correspond to about $56 \%$ of the 34 species known to the Vitória municipality (Ferreira et al., 2010) and 68\% of the recorded species ( $\mathrm{N}=13$ ) are endemic to the Atlantic Forest (Table 1). Regarding habitat requirements, the majority of the species in PEFG are open-landscape dependent (48\%), followed by generalist (31\%) and forest dependent (21\%). In a more preserved Atlantic Forest fragment situated in an inland mountainous region (about $80 \mathrm{~km}$
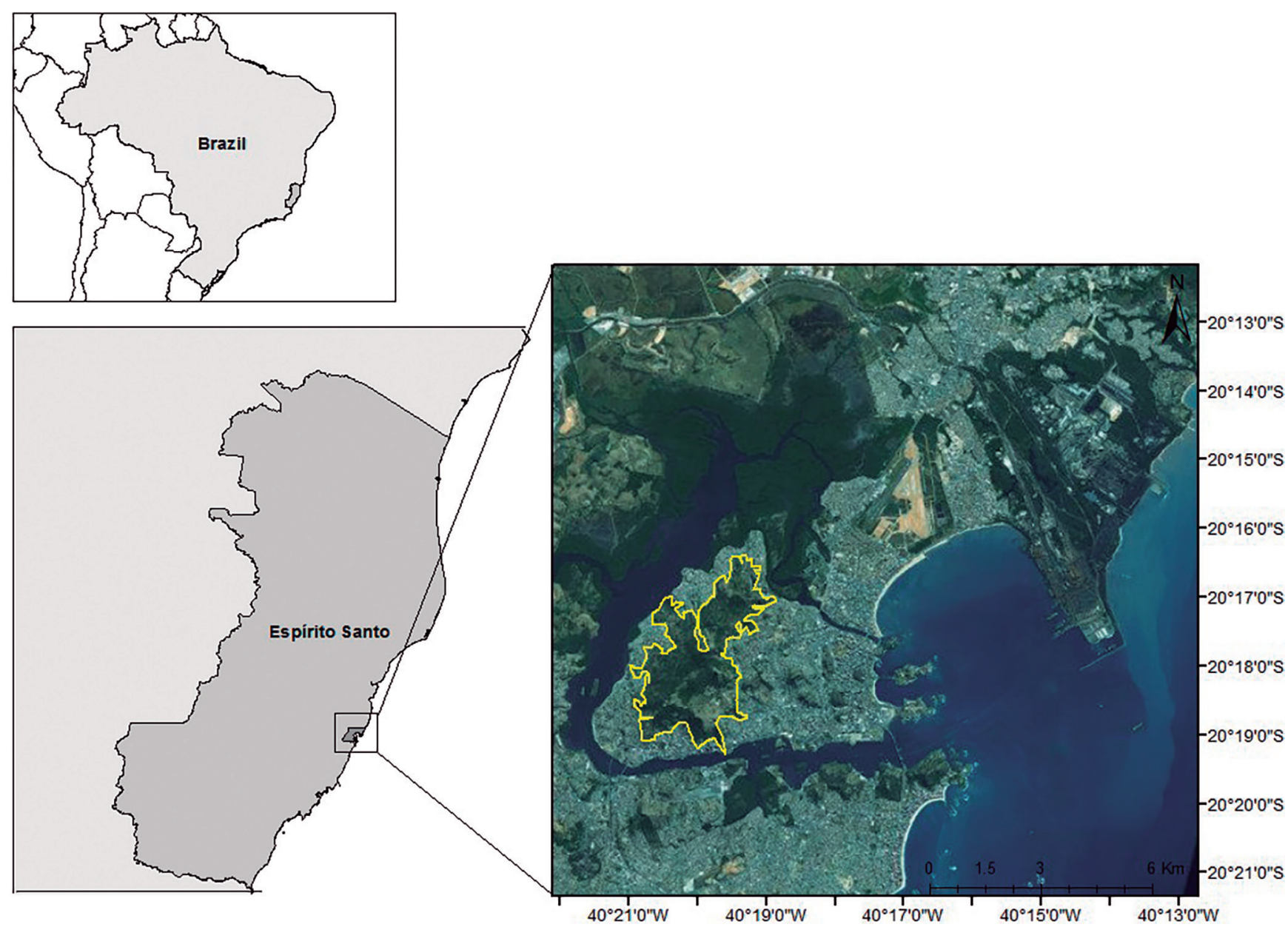

Figure 1. Map of the study location in the state of Espírito Santo, southeastern Brazil. In detail, Vitória municipality with delimitations of Parque Estadual da Fonte Grande (yellow contour). 
Table 1. Anuran composition of the Parque Estadual da Fonte Grande, municipality of Vitória, state of Espírito Santo, southeastern Brazil. Habitat requirements: $\mathrm{F}=$ Forest-dependent, $0=0$ pen-landscape dependent, and $\mathrm{G}=$ habitat generalist. *Endemic to Atlantic Forest. Conservation status of all species is Least Concern. Dspecies found during the day, Nspecies found during the night.

\begin{tabular}{|c|c|c|}
\hline Family Species & Population trends & Habitat \\
\hline \multicolumn{3}{|l|}{ Bufonidae } \\
\hline Rhinella crucifer (Wied-Neuwied, 1821) ${ }^{*, N}$ & decreasing & G \\
\hline \multicolumn{3}{|l|}{ Craugastoridae } \\
\hline Haddadus binotatus (Spix, 1824) ${ }^{*, D}$ & stable & $\mathrm{F}$ \\
\hline \multicolumn{3}{|l|}{ Cycloramphidae } \\
\hline Thoropa miliaris (Spix, 1824) ${ }^{*, D, N}$ & stable & G \\
\hline \multicolumn{3}{|l|}{ Hylidae } \\
\hline Boana albomarginata (Spix, 1824) ${ }^{*, N}$ & stable & 0 \\
\hline Boana faber (Wied-Neuwied, 1821) ${ }^{*, N}$ & stable & G \\
\hline Dendropsophus bipunctatus (Spix, 1824) ${ }^{*, N}$ & stable & 0 \\
\hline Dendropsophus branneri (Cochran, 1948) ${ }^{\mathrm{N}}$ & stable & 0 \\
\hline Dendropsophus decipiens $\left(\right.$ Lutz, 1925) ${ }^{\mathrm{N}}$ & stable & G \\
\hline Dendropsophus haddadi (Bastos \& Pombal, 1996)*,N & stable & 0 \\
\hline Scinax alter (Lutz, 1973) $)^{*, N}$ & stable & 0 \\
\hline Scinax cuspidatus (Lutz, 1925) ${ }^{*, N}$ & stable & 0 \\
\hline Scinax gr. ruber ${ }^{N}$ & No data & 0 \\
\hline Ololygon argyreornata (Miranda-Ribeiro, 1926) ${ }^{*, N}$ & stable & G \\
\hline Ololygon gr. perpusilla sp. nov. ${ }^{* 0, N}$ & No data & 0 \\
\hline Trachycephalus nigromaculatus Tschudi, $1838^{\mathrm{N}}$ & stable & $\mathrm{F}$ \\
\hline \multicolumn{3}{|l|}{ Leptodactylidae } \\
\hline Leptodactylus latrans (Steffen, 1815) ${ }^{\mathrm{N}}$ & stable & G \\
\hline Physalaemus crombiei Heyer \& Wolf, $1989^{*, D, N}$ & decreasing & $\mathrm{F}$ \\
\hline \multicolumn{3}{|l|}{ Odontophrynidae } \\
\hline Proceratophrys schirchi (Miranda-Ribeiro, 1937)*,D,N & decreasing & $\mathrm{F}$ \\
\hline \multicolumn{3}{|l|}{ Pipidae } \\
\hline Pipa carvalhoi (Miranda-Ribeiro, 1937) D,N & stable & 0 \\
\hline
\end{tabular}

away), most of the recorded species were also classified as open-landscapes dependent (58\%), followed by forest dependent (29\%) and generalist (13\%) (Silva-Soares \& Scherrer, 2013). However, in a cabruca agrosystem (i.e., mixed of forest and cacao plantation) in Atlantic Forest (about $90 \mathrm{~km}$ away), the majority of the species recorded are forest dependent (49\%), followed by open landscapes (35\%) and habitat generalists (16\%) (Teixeira et al., 2015). Variations in the habitat preferences of anurans across sites are perhaps a consequence of the different habitat

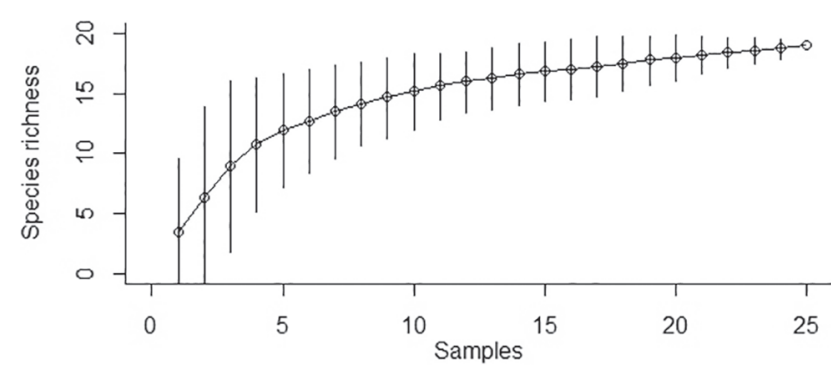

Figure 2. Species rarefaction curve of the anuran recorded at Parque Estadual da Fonte Grande, municipality of Vitória, state of Espírito Santo, southeastern Brazil. Vertical bars indicate the upper and lower limits of the confidence interval (95\%). types available to occupy and the degree of forest conservation. We detected a high proportion of open-landscape dependent species that include a new bromeliad frog (TSS; MMM; \& Hélio R. da Silva, unpubl. data), which increases the value of PEFG for anuran conservation.

Our results highlight the importance of well-studied urban fragments of the Atlantic Forest for anuran assembly. Although surrounded by urban landscapes, this forest refuge harbors 19 species of anurans, three of which (Rhinella crucifer, Physalaemus crombiei and Proceratophrys schirchi) with population decline (IUCN, 2017) and one new species that we found during this work (Silva-Soares et al. under description). This richness was probably related to the variety of habitat types in PEFG (permanent ponds, temporary and permanent streams, bromeliads, and forest leaf-litter) in which anurans have been reproducing. Thus, the conservation of these habitats may ensure the continuous viability and ecological functions of this anuran assembly in the present and into the future.

\section{ACKNOWLEDGMENTS}

We are grateful to Elaine Campinhos, Eliane Giori, Suzana Carvalho, Leonardo Zortea, Maria Carolina Stein, Paulo Victor Scherrer and Sulamita Marques for their assistance in the field. Rodrigo Barbosa Ferreira and Cora Jennings for English review. The Prefeitura Municipal de Vitória (PMV) especially Breno Platais, Camila Ramos, Felipe Fraga and security guards for logistical support. Instituto Chico Mendes de Conservação da Biodiversidade (ICMBio, SISBIO) and PMV for issued permits (processes 34836-4/2012 and 3764161/2012, respectively). TSS received funds from Conselho Nacional de Desenvolvimento Científico e Tecnológico (CNPq; PCI-DA). MMM received scholarships from Fundação de Amparo à Pesquisa e Inovação do Espírito Santo (FAPES) and Coordenação de Aperfeiçoamento de Pessoal de Nível Superior (CAPES). RBGC research was sponsored by FAPES (\#0611/2015).

\section{REFERENCES}

Almeida-Gomes, M. \& Rocha, C.F.D. 2015. Habitat loss reduces the diversity of frog reproductive modes in an Atlantic Forest fragmented landscape. Biotropica, 47: 113-118.

Alvares, C.A.; Stape, J.L.; Sentelhas, P.C.; Gonçalves, J.L.M. \& Sparovek, G. 2013. Köppen's climate classification map for Brazil. Meteorologische Zeitschrift, 22: 711-728

Auricchio, P. \& Salomão, M.G. 2002. Técnicas de coleta e preparação de vertebrados para fins didáticos e científicos. Arujá, SP,O Instituto Pau Brasil de História Natural. 348p.

Azevedo, C.0.; Kawada, R.; Tavares, M.T. \& Perioto, N.W. 2002. Perfil da fauna de himenópteros parasitóides (Insecta, Hymenoptera) em uma área de Mata Atlântica do Parque Estadual da Fonte Grande, Vitória, ES, Brasil. Revista Brasileira de Entomologia, 46: 133-137.

Brown-Jr., K.S. \& Freitas, A.V.L. 2002. Butterfly communities of urban forest fragments in Campinas, São Paulo, Brazil: Structure, instability, 
environmental correlates, and conservation. Journal of Insect Conservation, 6: 217-231.

CEBEA - Comissão de Ética Bioética e Bem-Estar Animal. 2013. Guia brasileiro de boas práticas para eutanásia de animais. Brasilia, Conselho Federal de Medicina Veterinária do Brasil.

Cushman, S.A. 2006. Effects of habitat loss and fragmentation on amphibians: a review and prospectus. Biological Conservation, 128: 231-240.

Diamond, J.M. \& Heinen, J.T. 2016. Conserving rare plants in locally-protected urban forest fragments: A case study from Miami-Dade County, Florida. Urban Forestry \& Urban Greening, 20: 1-11.

Duellman, W.E. \& Trueb, L. 1994. Biology of amphibians. Baltimore, Johns Hopkins University Press.

Estrada, A. \& Coates-Estrada, R. 2002. Bats in continuous forest, forest fragments and in an agricultural mosaic habitat-island at Los Tuxtlas, Mexico. Biological Conservation, 103: 237-245.

Felix, Z.I.; Wang, Y. \& Schweitzer, C.J. 2004. Relationships between herpetofaunal community structure and varying levels of overstory tree retention in northern Alabama: first-year results. In: Connor, K.F. (Ed). Proceedings of the $12^{\circ}$ Biennial Southern Silvicultural Research Conference. Asheville, Department of Agriculture, Forest Service, Southern Research Station.

Ferreira, R.B.; Silva-Soares, T. \& Rodder, D. 2010. Amphibians of Vitória, an urban area in south-eastern Brazil: first approximation. Salamandra, 46: 187-196.

Gandinetti, L. \& Jacobi, C.M. 2005. Distribuição estacional e espacial de uma taxocenose de anuros (Amphibia) em uma área antropizada em Rio Acima, MG. Lundiana, 6: 21-28.

Griffo, C.L.S. \& Silva, A.G. 2013. As unidades de conservação do município de Vitória no novo contexto do Sistema Nacional de Unidades de Conservação. Natureza on line, 11: 54-67.

Haddad, C.F.B.; Toledo, L.F.; Prado, C.R.A.; Loebmann, D. \& Gasparini, J.L. 2013. Guia de Anfibios da Mata Atlântica: diversidade e biologia. São Paulo, Anolis Books.

IUCN - International Union for the Conservation of Nature. 2017. Available at: www.iucnredlist.org. Access in: 10/10/2017.

Kindt, R. 2016. Biodiversity R: package for community ecology and suitability analysis. R version 2.7-1.

Martins, A.; Pontes, R.; Mattedi, C.; Fratani, J.; Murta-Fonseca, R.A., Ramos, L. \& Brandão, A.L.R. 2014. Anuran community of a coastal Atlantic Forest fragment in the state of Rio de Janeiro, Southeastern Brazil. Salamandra, 50: 27-39.

Miyashita, T.; Shinkai, A. \& Chidac, T. 1998. The effects of forest fragmentation on web spider communities in urban areas. Biological Conservation, 86: 357-364.

Pontes, A.R.M. \& Soares, M.L. 2005. Sleeping sites of common marmosets (Callithrix jacchus) in defaunated urban forest fragments: a strategy to maximize food intake. Journal of Zoology, 266: 55-63.

R Development Core Team. 2016. R: A language and environment for statistical computing. R Foundation for Statistical Computing. Available at: www. scirp.org/(S(351jmbntvnsjt1aadkposzje))/reference/ReferencesPapers. aspx?ReferencelD $=1792512$.

Ribeiro, M.C.; Metzger, J.P.; Martensen, A.C.; Ponzoni, F.J. \& Hirota, M.M. 2009. The Brazilian Atlantic Forest: How much is left, and how is the remaining forest distributed? Implications for conservation. Biological Conservation, 142: 1141-1153.

Rocha, C.F.D.; Bergallo, H.G.; Pombal-Jr., J.P.; Geise, L.; Van-Sluys, M.; Fernandes, M. \& Caramaschi, U. 2004. Fauna de anfíbios, répteis e mamíferos do estado do Rio de Janeiro, sudeste do Brasil. Publicações Avulsas do Museu Nacional, 104: 3-23.

Rodrigues, J.J.S.; Brown-Jr., K.S. \& Ruszczyk, A. 1993. Resources and conservation of neotropical butterflies in urban forest fragments. Biological Conservation, 64: 3-9.

Silva-Soares, T. \& Scherrer, P.V. 2013. Amphibians of Parque Estadual do Forno Grande, State of Espírito Santo, Southeastern Brazil: Species composition and conservation. North-Western Journal of Zoology, 9: 113-120.

Tabarelli, M.; Aguiar, A.V.; Ribeiro, M.C.; Metzger, J.P. \& Peres, C.A. 2010. Prospects for biodiversity conservation in the Atlantic Forest: Lessons from aging human-modified landscapes. Biological Conservation, 143: 2328-2340.

Teixeira, R.L.; Ferreira, R.B. \& Rodder, D. 2008. Diversity and abundance variations of anurans at a permanent pond in Suruaca's valley, Linhares, Espirito Santo, Southeastern Brazil. Amphibia, 7: 20-25.

Teixeira, R.L.; Ferreira, R.B.; Silva-Soares, T.; Mageski, M.M.; Pertel, W.; Rödder, D.; Barros, E.H. \& Engler, J.0. 2015. Anuran community of a cocoa agroecosystem in southeastern Brazil. Salamandra, 51: 259-262.

Tsuji-Nishikido, B.M. \& Menin, M. 2011. Distribution of frogs in riparian areas of an urban forest fragment in Central Amazonia. Biota Neotropica, 11: 63-70. 